\title{
DO CORAÇÃO À CANETA: CARTAS E DIÁRIOS PESSOAIS NAS TEIAS DO VIVIDO (DÉCADAS DE 60 A 70 DO SÉCULO XX)1
}

\author{
From the heart to the pen: letters and personal \\ diaries in the web of life in the 1960s and '70s)
}

\author{
Maria Teresa Santos Cunha*
}

\begin{abstract}
RESUMO
Este texto pretende discutir algumas possibilidades de abordagem das sensibilidades na História, considerando que somos tributários de diferentes situações que envolvem afetividades e que podemos problematizá-las como práticas e registros que ocorrem em espaços diversificados e temporalidades distintas. Neste território se manifestam e se materializam linguagens multifacetadas e representações complexas e contraditórias, com as quais mulheres e homens vivem e reinventam seu cotidiano. Nesta perspectiva, documentos pessoais, como cartas e diários, são tratados como práticas sociais que partilham da constituição de um regime de sensibilidades, ou seja, da construção da história de indivíduos que, nos segredos da intimidade, se inventam pela escrita de si e pela escrita para os outros.
\end{abstract}

Palavras-chave: cartas; diários femininos; sensibilidades; cultura escrita.

\begin{abstract}
This text discusses some possible approaches to the sensibilities in history, considering that we are tributaries of different situations that involve emotions and that we can problematize them as practices and registers that occur in a variety of spaces and times. In this territory, multifaceted languages are materialized as well as the complex and contradictory representations with which women and men live and

" Programa de Pós-Graduação em História/ UDESC

1 Os diários femininos e as cartas aqui analisadas integram o acervo pessoal da autora, por meio de doações espontâneas de suas proprietárias. Com estes documentos, vários trabalhos já foram realizados e alguns deles estão listados nas referências.
\end{abstract}


reinvent their daily lives. From this perspective, personal documents such as letters and diaries are treated as social practices that share the constitution of a regime of sensibilities, that is, of the construction of the history of individuals that, in the secrets of intimacy, invent themselves through writing and the writing of others.

Keywords: letters; women's diaries; sensibilities; written culture.

História é aquela certeza fabricada no instante em que as imperfeições da memória se encontram com as falhas da documentação.

(BARNES, 2012, p. 23)

Cartas e diários pessoais são documentos que carregam traços ritualísticos, consagrando-se tanto como artefatos culturais quanto como documentos que têm, para o historiador, outros estatutos: abrir espaço a partir do qual a história pode ser investigada, isto é, buscada em vestígios e problematizada a partir de diferentes ritmos da vida social de uma época. Materializados em papel e tinta, eles eternizam, em folhas amarelecidas pela passagem do tempo, ideias, saberes, valores, acontecimentos e dizeres: representações escritas em suporte papel de um outro tempo, produzindo sentidos e construindo significados à ordem do existente.

Considerando seu caráter de objetos frágeis e, muitas vezes, portadores de segredos pessoais, estes materiais ficaram esquecidos e, não raro, guardados silenciosamente ou escondidos em baús e caixas que, em geral, não estão preservados em arquivos públicos. Quando visibilizados, despertam o interesse do historiador e podem se fazer ouvir historicizados em uma relação entre a experiência vivida e as representações.

O presente trabalho pretende discutir algumas possibilidades de abordagem desses materiais como portadores e construtores de sensibilidades na História, considerando que eles são tributários de diferentes situações que envolvem afetividades e podem ser problematizados como práticas discursivas e registros que ocorrem em espaços diversificados e temporalidades distintas. Assim, cartas e diários pessoais partilham da constituição de um regime de sensibilidades, ou seja, da construção da história 
de indivíduos que, nos segredos da intimidade, se inventam pela escrita de si e pela escrita para os outros.

Neste território se manifestam e se materializam, por escrito, registros multifacetados e representações complexas e contraditórias, com as quais mulheres vivem e reinventam seu cotidiano, permitindo-nos seguir suas reações e, no limite, suas emoções diante dos fatos narrados. Esta reflexão coloca em cena uma maneira diferenciada para pensar a História em conjunção com as sensibilidades que dão forma à vida cotidiana e à contemporaneidade em seus diferentes matizes, dadas a ver por uma "riqueza de vestígios deixados por homens e mulheres que não fizeram história na acepção clássica do termo, mas viveram, simplesmente, suas vidas [...] uma história nem sempre feliz, mas, em todo o tempo, bela" (ERTZOGUE; PARENTE, 2006, p. 15-16).

\section{Das cartas e seus fragmentos}

Em tempos de internet e formatos de letras comandados pelas variadas opções dos editores de texto, algumas pessoas ainda dão importância à velha arte de escrever cartas e preservam amizades e laços familiares por meio dessa forma de comunicação. Palavras escritas à mão, sempre com caneta tinteiro de tinta azul, materializadas em simples e banais folhas de arquivo escolar, as cartas seguiam pelo correio e celebravam a amizade entre Cláudia (C.) e Lúcia (L.) $)^{2}$, jovens professoras à época (1967), com 21 e 18 anos, respectivamente. No período compreendido entre $1 .^{\circ}$ de agosto de 1967 e 19 de junho de 1968, C. enviou, de Curitiba, no Paraná, 171 cartas para L., que vivia em Caçador, no Estado vizinho de Santa Catarina. L. conservou estas cartas e, hoje, elas compõem um acervo pessoal com 349 folhas escritas e que se constituiu em documento para o presente trabalho.

Por escrito, elas compartilharam segredos, aconselharam-se mutuamente, explicitaram relações com os membros do seu grupo social e, muito minuciosamente, trocaram experiências sobre sua profissão de professoras e suas vidas cotidianas.

2 Os nomes das autoras das cartas em estudo serão, doravante, citados pelas iniciais C. e L. 


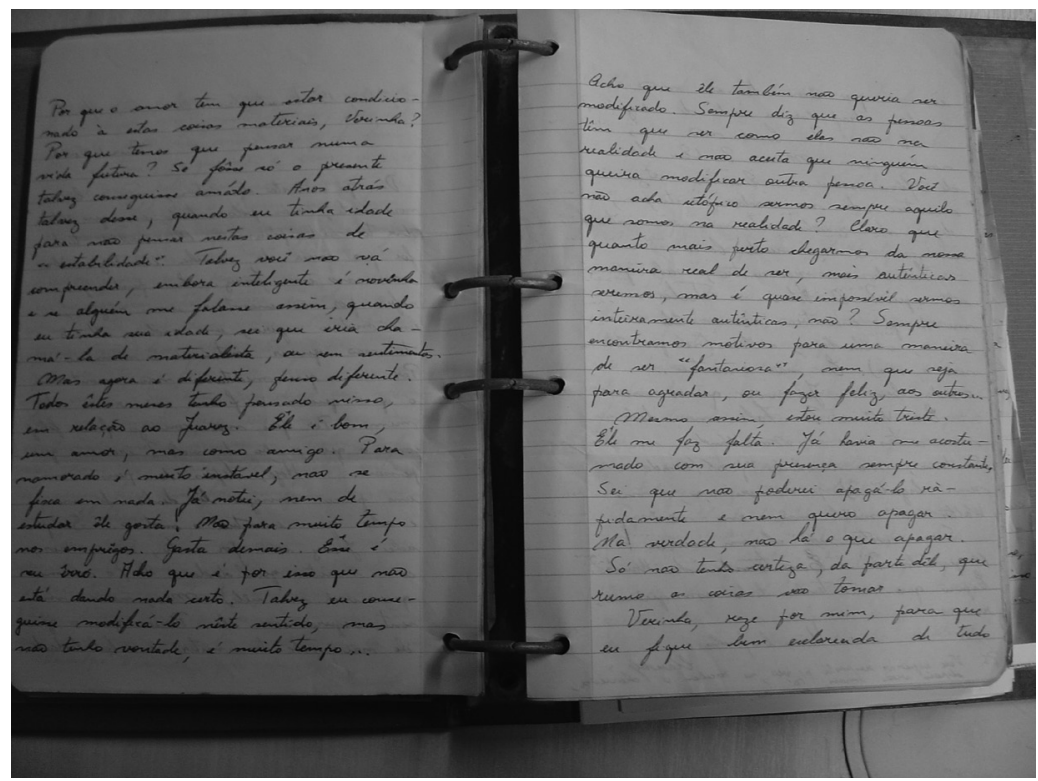

FIGURA 1 - ARQUIVO DE CARTAS DE L. (1967-1968).

FONTE: Acervo pessoal da autora.

A partir da análise de trechos dessas cartas, procurar-se-á dar ênfase às narrativas que tratam do cotidiano destas mulheres/professoras e às representações escritas de situações vividas no dia a dia, no privado e na sala de aula. De igual maneira, buscar-se-á realçar o modo como as missivistas escreveram, as condições de produção dessas cartas, ou seja, que campos desenharam na plataforma do escrito; que regime de historicidade (HARTOG, 2006, p. 263) é possível encontrar nessa documentação para fazer vir à tona uma história de sujeitos se construindo e se inventando pela escrita, uma possibilidade de "capturar sensibilidades do passado, através dos traços objetivos que estas deixaram para o presente" (PESAVENTO, 2006, p. 177).

As 171 cartas escritas por C. recebidas e arquivadas por L. oferecem ao historiador do presente vestígios de suas experiências individuais e relações familiares, o que se reveste, por princípio, em "fontes que o 
historiador não pode prescindir em seu ofício e que servem igualmente a outros estudiosos que se interessam por algum aspecto da vida humana, quer seja relacionada à linguagem, à escrita, à educação, às mentalidades ou aos costumes" (CASTILLO GÓMEZ, 2001, p. 16).

Desde a última década do século XX, vêm se intensificando os estudos sobre escritas cotidianas e práticas epistolares das pessoas comuns, chamadas de escrituras ordinárias ou escritos sem qualidades (FABRE, 1997) ${ }^{3}$, abrindo, cada vez mais, um campo para as pesquisas sobre práticas e funções culturais da escrita na sociedade letrada que se desenvolveu a partir do século XIX. Como tema de estudo, as cartas são consideradas como "objetos nos quais estão imbricadas práticas sociais" (CAMARGO, 2000, p. 205) e, como tal, são passíveis de análises que trazem para a História a emergência da subjetividade a partir das aventuras da individualidade. Capturar razões e sentimentos exige articular práticas culturais (no caso em estudo, as práticas de ler e escrever) a experiências que expressam os sentidos que estas mulheres, em dado momento da história, foram capazes de atribuir a si próprias e à realidade construída.

$\mathrm{O}$ ato de escrever cartas pessoais consiste em confrontar-se com códigos estabelecidos e, a partir deles, inventar/construir um lugar para si, por meio das palavras. Trocar cartas, corresponder-se ou escrever para alguém são formas de se expor, compartilhar experiências, vencer distâncias e ausências, tecer sensibilidades, enfim, construir laços de papel.

A carta, como uma prática de escrita, partilha da constituição de um regime de sensibilidades/sociabilidades, ou seja, fala tanto de quem a escreve como revela sempre algo sobre quem a recebe, anunciando a intensidade do relacionamento entre os envolvidos, pois "nunca se escreve senão para viver, a fim de fazer frente a uma situação, para explicar, justificar-se, informar, dirigir-se a, apelar, queixar-se, sofrer menos, fazer-se amar, dar-se prazer" (BOLLÉME, 1988, p. 201). A troca de correspondências permite, também, a busca do eu, a escrita de si, a reflexão, a introspecção, já que "escrever é mostrar-se, dar-se a ver, fazer aparecer o rosto próprio junto ao outro [...] De certo modo, a carta proporciona um face a face [...] pois cada um aí deve desvelar sua alma" (FOUCAULT, 2000, p. 200-210).

3 As escrituras ordinárias ou sem qualidades são aquelas realizadas pelas pessoas comuns e que se opõem aos escritos prestigiados, elaborados com vontade explícita de "fazer uma obra" para ser impressa. 
As cartas aqui estudadas, trocadas por duas jovens mulheres nos finais da década de 60 do século XX, praticam com particular intensidade e atenção um estilo confessional e autorreferente que se intensifica ao longo do tempo em que dura a correspondência e enseja considerar esta prática de escrita pessoal como "um dos meios para alcançar não só um domínio do tempo que passa, mas também uma representação estável de si” (HÉBRARD, 2000, p. 30).

A troca de intimidades e sentimentos permite pensar sobre um pacto epistolar, considerado como "uma espécie de contrato assinado de modo tácito por aqueles que se correspondem" (LYONS, 1999, p. 66). Logo na primeira carta já é possível identificar esta estratégia quando C. comunica que vai escrever o que lhe vem à cabeça, afirmação que anuncia o grau de intimidade entre as amigas, uma intimidade expressada pela troca de confidências que requerem confiança, entrega, disposição de ir além da mera transferência de informações. Os textos abaixo transcritos das cartas parecem ser bem reveladores:

Que há de errado em mim? Por que não consigo saber o que há? Sou egoísta. É triste a escuridão (29/08/1967)

Você é minha confidente. Nós combinamos escrever aquilo que se tem vontade na hora. $(02 / 08 / 1967)$

Como objetos materiais, recheados de práticas culturais de uma época, as cartas trazem marcas da modelização de práticas de escritas escolares, seja na caligrafia caprichada, seja nos borrões disfarçados e até na observância dos protocolos de correspondência ensinados em tantos manuais que circularam no espaço escolar como, por exemplo, aqueles que normatizavam o uso correto das linhas tracejadas ou mesmo as formas de tratamento cerimoniosos ensinadas, como o proposto: "para se escrever é necessário que se tenha bom papel [...] envelope liso [...] observar as saudações corretas e utilizar sempre tinta azul - a mais razoável" (CARVALHO, 1989, p. 87-88).

No âmbito de uma história das sensisibilidades, cartas são documentos por meio dos quais é possível apreender elementos para a construção 
de uma história comum a um grupo. No caso em estudo, seguindo-se um cerimonial epistolar cujos primórdios remontam aos finais do século XIX (FOISIL, 1991) e anunciam o que se pode chamar de "a gramática social da escrita privada" (LYONS, 1999, p. 61), é importante salientar alguns rituais do ato de escrever presentes nas cartas de Cláudia para Lúcia. Ao atentar para eses aspectos internos, é importante considerar as condições de produção das cartas, uma vez que "os interlocutores não estão na presença um do outro, mas, assim mesmo, pela intermediação de um objeto escrito, se desenvolve também um jogo interativo" (DAUPHIN; POUBLAN, 2002, p. 83).

As cartas iniciavam-se, sempre, pela localização espaço-temporal, prosseguiam com um vocativo carinhoso, em geral no diminutivo - Querida Lucinha - e finalizavam-se com palavras saudosas que recordavam a distância e a ausência e que, ao mesmo tempo, anunciavam o prosseguimento do assunto para o dia seguinte com a expressão sempre recorrente - Por hoje é só. Os locais onde as cartas estão sendo escritas aparecem sempre destacados e dizem respeito aos espaços, tanto públicos como privados, por onde a remetente circula, quais sejam: na escola; enquanto os alunos fazem os exercícios em silêncio; durante a aula dada pela aluna-mestra; na cama, antes de dormir; no sofá novo da sala; na mesa da sala; antes de ser servido o almoço; na janela, escutando os pássaros; enquanto espera a chegada do namorado. Pela leitura, é possível imaginar as muitas cenas descritas, vivê-las imaginariamente, tal a riqueza de detalhes em que são descritas: presenças, sons, odores, objetos, são os signos que intervêm no tempo real da escritura. A escrita, por sua vez, é movida e registrada pelas amigas como capaz de despertar sentimentos como compartilhar meus segredos; dividir minhas dúvidas; ouvir sua opinião; deliciar-me com sua inteligência.

Assim, as cartas de Cláudia, pela sua arquitetura, esquadrinharam dispositivos que produziram e alimentaram sensibilidades, moldaram afetos e inteligências, escreveram um tempo, registraram episódios que legitimaram o ato da escrita na constituição de suas individualidades como sujeitos que, pela escrita, partilhavam detalhes do dia a dia onde viveram e escreveram/inventaram suas vidas. 


\section{Um tempo nas cartas de C. e L.}

O período abarcado neste estudo (1967 e 1968) reveste-se de um caráter de excepcionalidade na vida política do Brasil. Vivia-se em um regime de exceção. O Golpe Militar de 1964 deu início a um dos períodos mais turbulentos da história recente brasileira, que se estendeu até os inícios da década de 80. Quase tudo na vida nacional se definia na arbitrariedade, nas cassações de cidadania, na censura cultural, nos exílios e na busca implacável daqueles que resistiam em aceitar e seguir as normas impostas pela ditadura militar. As cartas não falam quase nada sobre este momento. As notícias são muito escassas, o que permite pensar que, para a missivista, a situação do país habitava uma zona de silêncio, um território do vazio. De todo o conjunto epistolar examinado, só foi possível encontrar breves e sutis referências ao período político, embutidas em comentários gerais sobre peças teatrais que foram assistidas e um episódio a respeito de programa televisivo visto por $\mathrm{C}$. em Curitiba e cuja descrição à amiga deixa entrever uma desinformação sobre a vida política do país que, neste período, estava bastante conturbada pela ampla violação dos direitos humanos (prisões arbitrárias, torturas, repressão).

Fiquei vendo televisão até agora, pela TV, o último dia do festival de música popular. Estava tão bom! Você precisa ver, Lucinha, a hora em que aquele cantor quebrou o violão e jogou-o na plateia dizendo: Vocês ganharam, povo subdesenvolvido! Antes eu havia achado grossura dele fazer aquilo, mas vi o programa e dei-lhe o meu inteiro apoio. Acho que no seu lugar, jogava violão e até o piano, se fosse possível. Povo pobreza, mesmo! E era a elite de São Paulo. Este programa não pode ser passado no exterior, seria uma vergonha para o Brasil. (07/11/1967)

Sendo C. universitária, professora, moradora de um grande centro urbano do sul do país, seu silêncio sobre o momento político crucial pode ser interpretado tanto como uma despolitização da vida pessoal como uma percepção de tempo como experiência interna, marcada por eventos fundadores estabelecidos a partir de suas vivências pessoais e que criam 
possibilidades de pensar que tais fatos não careciam de maior relevo no vivido cotidiano.

Vestígios de um tempo podem ser encontrados nas singelas cartas de Cláudia para Lúcia. São registros de aspirações miúdas, quase murmúrios interiores que, na plataforma do escrito, assumem um papel de permanência e estabilidade, sobreviventes que são das chamas e do lixo que parece ser o destino comum dessas letras, desses escritos ordinários que zelosamente preservados estão aí "para ocultar tanto quanto para revelar. Mas essas sutis manipulações do esconder/mostrar nos levam, pelo menos, à entrada da fortaleza" (PERROT, 1991, p. 11).

Nas cartas, entre uma notícia e outra, nos espaços marginados pelas folhas de arquivo, estão impressos dizeres e fazeres, amarelecidos pelo tempo, e onde se pode encontrar sedimentados tanto aspectos do cotidiano e relações entre o sujeito e os outros e entre o sujeito e ele mesmo. Nesse aspecto, as cartas abrem espaço tanto para o historiador conhecer as condições de produção que conformam o território de uma história social da cultura escrita como para apreender fatos e redes de laços afetivos múltiplos, ou seja, traduzir o mundo em sentimentos.

\section{Notícias do cotidiano escolar nas cartas}

Em todo o conjunto de cartas escritas por Cláudia para Lúcia, um assunto bastante comentado e alvo de longas narrativas diz respeito às labutas de seus cotidianos escolares de professoras do chamado ensino primário. Pela constância com que este tema aparece, é lícito considerar-se que o fato de ter a mesma profissão fornecesse o terreno propício para a troca de experiências entre as duas amigas e correspondentes. Inúmeras situações são descritas e acabam dando o tom para o desenvolvimento da escrita, até pelo fato de que muitas cartas foram escritas por Cláudia, inclusive, no próprio ambiente escolar.

Escrevo para você enquanto meus alunos fazem exercícios de matemática. (05/08/1967) 
Escrevo durante a aula da aluna-mestra. (10/10/1967)

A atuação de Cláudia como professora encontra-se investida de uma carga afetiva e de um valor existencial que qualificam a profissão como uma escolha acertada para sua vida e muitas notícias ratificam isto:

Adoro ser professora e ensinar crianças. (20/12/1967)

C. sempre dá notícias do seu cotidiano escolar, quer como professora quer como aluna de Pedagogia, e, ao mesmo tempo, procura saber da amiga sobre suas atividades e a encoraja a prosseguir na carreira do magistério:

Como vão suas aulas? Queria que você me falasse sobre elas, é tão bom ouvir alguém que está começando e tem bastante para dar, sem muita preguiça. Sabe, isso nos dá forças e ânimo, ou ainda, vontade se ser igual. Só ter vontade é algo muito bom. $(17 / 08 / 1967)$

E você, já começaram seus serviços? Fiquei alegre em saber dos seus progressos no campo do magistério. (01/03/1968)

Pela passagem do "Dia do Professor" - 15 de outubro 4 -(VICENTINI, 2000), as notícias giram em torno das homenagens recebidas e a ocasião propicia que se fale sobre a carreira do magistério em cartas sucessivas e esta frequência indica o prestígio que a profissão ainda tinha na sociedade:

Em primeiro lugar parabéns pelo seu dia. Tudo de bom na sua carreira maravilhosa (deixa eu falar da minha, tá?). As flores vêm chegando a toda hora. Nossa casa está enfeitada. $(15 / 10 / 1967)$.

4 Sobre a comemoração do Dia do Professor no Brasil, ver o trabalho de VICENTINI, Paula Perin. Imagens e representações na história da profissão docente no Brasil (1945-1964). Relatório do Exame de Qualificação (Doutorado/USP), 2000, especialmente o item 3, "Prestígio e pobreza: o Dia do Professor na história da profissão docente". p. 78-101. 
No dia seguinte, outra carta registra a sequência das homenagens:

Meus alunos prepararam uma festa para mim e tive urna enorme surpresa quando entrei na sala. Minha mesa estava forrada de tortas e bolos e ganhei vários chaveiros de presente. Flores, então, nem se fala. Acho que vou ter que comprar alguns vasos lá em casa, pois nem encontrei lugar para colocá-las. $(16 / 10 / 1967)$

A relação com os alunos e alunas é descrita, muitas vezes, envolta por um halo de carinho maternal. As crianças são chamadas de pequenos filhos, anjinhos, aluninhos e sempre precedidos dos pronomes possessivos meus.

Meus anjinhos estão em prova e hoje fazem matemática $(28 / 11 / 1967)$

Estou na sala de aula (5 $5^{\circ}$ ano). Meus pequenos filhos fazem exercício de gramática e eu aproveito (se bem que não está certo) o tempo para lhe responder a carta de ontem. Você merece. $(07 / 08 / 1967)$

O fato de referir-se aos alunos como filhos e anjinhos mostra, ainda, uma dada permanência do "magistério como uma extensão da maternidade, em que cada aluna ou aluno era representado como um filho ou filha espiritual e a docência como uma atividade de amor e doação à qual acorreriam aquelas jovens que tivessem vocação" (LOURO, 1997, p. 451). Entretanto, inúmeras vezes, C. também vai falar de seus alunos e alunas de maneira até irônica, vai queixar-se deles e de suas atitudes em sala de aula, o que permite pensar que o espaço privado da escrita cria condições para um certo desnudamento, para uma certa exteriorização dos sentimentos imanentes à prática epistolar:

[...] depois alunos pela manhã, alunos pela tarde, sempre alunos. Francamente, 'estou "até aqui" de alunos [...]. Quero esquecer que sou professora... Nós não vamos mais falar muito de aulas, não é? (04/12/1967). 
O sentimento do dever e a responsabilidade da função estão sempre presentes. No início do $2^{\circ}$ semestre letivo do ano de 1968 , C. escreve uma longa carta em que se recrimina à amiga L. por sua suposta fraqueza no trato com os alunos:

Acho que estou ficando "fracota". Se chego em casa morrendo não é por culpa deles, mas sim, da minha fraqueza. Acho que já perdi aquelas forças superiores que toda professora deve ter. Isto não é nada bom! (08/08/1968)

Merece registro o elevado grau com que C. via e representava o papel de professora: como alguém com forças superiores, um ser especial que não se esgotaria nas suas dimensões técnicas de apenas dominar o conteúdo. Situação semelhante é contada em outra carta, em que sinaliza para o senso de dever:

Pena que eu tenha tantas provas para corrigir, gostaria de continuar conversando com você, é sempre tão bom! Mas o dever... você sabe! Deverei entregar as notas até amanhã e estou atrasadíssima, pois só hoje apliquei o teste em todas as turmas. Vai ser "fogo", mais uma madrugada acordada, corrigindo provas! Não importa, o essencial é ter paz de espírito, o resto fica tudo mais fácil. (27/09/1967)

As cartas vão se constituir em pequenos lugares onde se quebra o silêncio sobre o imaginário de enobrecimento que cerca a figura da professora. Mesmo que esteja presente, ainda, um discurso de doação, renúncia, há uma reafirmação de imagens que, pelo ato criador na escrita, inscrevem o sujeito-professora mais distanciado do discurso absolutizador que enobrecia a profissão docente, aquele que veiculava que para ser professora era preciso estar na condição de um ser superior, capaz de superar as questões cotidianas e se entregar, com abnegação, à causa escolhida. Os estudos de Denice Catani (1997) mostram, por sua vez, que

[...] neste vocabulário de abnegação e devotamento, as professoras quase não tiveram lugares de dizer de seus demônios, 
das decepções, da mesquinharia da formação, de experiências de violência que sofreram, do tédio dos cursos, da insolúvel contradição entre teoria e prática, de todo um processo que acabou, enfim, por lançá-las, na sala de aula, numa inexprimível solidão (p. 28-29).

O relato de fragmentos da vida de professora e aluna de um curso de Pedagogia, cuja construção se deixa entrever nas cartas, cria, pelo conteúdo informativo da carta, um jogo interativo entre remetente/destinatário onde C., ao apresentar-se e apresentar suas atividades minuciosamente, constrói a representação que lhe é mais conveniente.

Considerando-se que L. tinha desejos de cursar uma faculdade e já era professora primária em Santa Catarina, parece significativa a abundância de relatos sobre o assunto: as aulas dadas, os alunos, o tempo regido pelas atividades escolares; as dificuldades e percalços do ofício de ensinar. $\mathrm{O}$ relato dos fazeres e pensares em sala de aula se intensifica quando C. passa a contar sobre as novas propostas de ensino que diz estar aprendendo na faculdade de Pedagogia. Tudo indica que na sala de aula a teoria se atualiza, não raro sendo confirmada, outras vezes não preenchendo as expectativas da professora, mas sempre provocando a busca e a criação de alternativas para sua atuação no magistério, como aparece explicitado nas cartas abaixo:

Todas as técnicas de orientação que aprendi o ano passado e que aprenderei este ano nos meus estágios quero ver se aplico-as no $5^{\circ}$ ano. No primeiro dia de aula já aproveitei para aplicar um teste. Os resultados eu os coloquei em cada ficha. É bom mesmo começar desde o $1^{\circ}$ dia para não atrapalhar o bom andamento do serviço. Quero que minha turma seja o modelo, não só do colégio, como das turmas que já tive até hoje e terei. (08/08/1968)

Tive três aulas fabulosas, ontem e hoje, de Psicopatologia, Psicoterapia e Testes. Estou bem entusiasmada com meu curso que está cada vez mais para frente, só que está muito pesado. Tenho saído da faculdade, todos os dias, às 8 horas e será assim todos os dias, mas não faz mal, pelo menos se aproveita muito, prefiro assim que uma coisa "matada”. (18/08/1967) 
Longas cartas no mês de novembro de 1967 enfatizam a defesa das atividades práticas desenvolvidas pelo Professor M. em aulas de Psicoterapia. São descrições das técnicas de dinâmica de grupo, experiências de trabalhos em equipe que, para a época, eram bastante novas, como hipnotismo realizado pelo professor em sala de aula. Por meio destas práticas de escrita epistolar é possível perceber uma preocupação que transcende o conteúdo que se quer transmitir, visto haver uma preocupação com a forma como a correspondência chega a seu destinatário. É importante ressaltar, neste aspecto, outras preocupações da ordem do simbólico expressas pelas desculpas com o tamanho e feitio da letra e mesmo a troca de caneta que alterava a grafia usual, além da presença de outras pessoas no ambiente em que estava sendo escrita a carta e que "inibiam" a livre expressão da autora. Estes detalhes, aparentemente ínfimos, possibilitam ao historiador reconhecer aspectos das condições de produção de correspondências, as imposições simbólicas e materiais que instituíam um regime de escrita no período em questão, das teias de sensibilidades tecidas pela escrita e a observância às formas modeladoras, em geral prescritas pela escola:

Desculpe a letra feia e os rabiscos. A letra foi por causa da bebida e os rabiscos foi [ram] descuido meu e dessa caneta ruim. $(04 / 11 / 1967)$

Estou escrevendo às pressas, sem muito tempo, sem muito capricho com a letra porque quero enviar a carta hoje. (31/08/1967)

Hoje tenho que ser breve porque a sala está cheia de gente, o quarto está com tinta fresca e perto deles é dificil me concentrar para falar seriamente com você. Amanhã espero que tudo volte ao normal. $(10 / 05 / 1968)$

Estes papéis do passado, guardados em um arquivo e zelosamente preservados por L., mostram um lugar possível de diálogo entre duas amigas que estão distantes. A análise desse material, em seus suportes, conteúdos e condições de produção, ainda que pouco explorada, requer problematizar grades conceituais com perspectivas totalizadoras e, dessa forma, os estudos do historiador espanhol António Viñao Frago (1999) fornecem 
base epistemológica ao argumentar que tais objetos requerem "modos de aproximação de índole etnográfica, um enfoque centrado em espaços sociais restritos e práticas bem definidas [...] e configurados em um espaço e um tempo determinados" (p. 294).

As cartas como escrituras ordinárias mostram em traços firmes e/ou inseguros uma relação pessoal com o universo da escrita, por meio delas "abre-se a possibilidade de (re)conhecer outras maneiras de viver e de narrar o vivido. Com elas, enfim, 'devolvemos' uma certa visibilidade a muitos protagonistas anônimos do acontecer coletivo" (CASTILLO GÓMEZ, 2000, p. 11).

Para além das interpretações que suscitam, o trabalho procurou mostrá-las, também, em suas várias formas materiais, tentando compreender em que situações do cotidiano dessas mulheres e professoras estas possibilidades de estabelecer correspondências eram instauradas. Assim, não só o conteúdo do que estava "indo" e "vindo" pelos Correios, mas, o "onde" e o "como" elas estavam sendo produzidas. Citando Chartier (1994, p. 12), é possível pensar que "a tarefa do historiador é, então, a de reconstruir as variações que diferenciam os espaços legíveis - isto é, os textos nas suas formas discursivas e materiais ${ }^{5}$ - ou seja, as leituras compreendidas como práticas concretas e como procedimentos de interpretação".

$\mathrm{O}$ trabalho com as cartas pretendeu empreender, ainda que sem quaisquer garantias de finalização, uma história de um regime de escrita construtor de sensibilidades. Pretendeu-se mostrar que a correspondência entre pessoas comuns pode iluminar práticas, hábitos e valores, construir representações de época e como por meio delas as pessoas se constroem/ se inventam na e pela escrita, um ato criador que inscreve/escreve o sujeito nas mais variadas formas.

Cláudia derramando-se em 171 cartas, cobrindo a simplicidade do seu presente, e Lúcia arquivando e preservando esta memória de papel, criaram condições para que se visse mais e diferentemente outros eventos, acontecimentos, lugares, situações e, pela singularidade de uma escrita, confirmam a sensação de que o escrever é, além de uma forma de contornar a ausência pela escrita da memória, uma tentativa de suplantar a finitude. Estas personagens comuns e ordinárias e suas singelas cartas abrem frestas

tensão.

5 O grifo é meu para destacar que o esforço, neste trabalho, tem sido o de perseguir esta 
para a decifração dos mistérios da aventura humana que, afinal, é o que move o historiador para a compreensão dos fundamentos de nossa contemporaneidade, por meio da sensibilidade de observador que interpreta indícios.

\section{De diários pessoais e seus fragmentos}

Outra forma de inscrição de memória, quase sempre narcísica e contemplativa, são os diários pessoais. Os diários em estudo neste trabalho foram escritos à mão entre décadas de 1960 e 1970; falavam de si e, em geral, para si mesmos. Apresentados em grossos cadernos escolares, ilustrados com recortes e colagens, praticados na intimidade, relatando fatos e situações em sua aparente insignificância com riqueza de detalhes, se constituem tanto em refúgios do eu como em repositórios de lembranças. Escrito ao longo dos dias, seu objetivo parece ser o de apresar em suas páginas o passar do tempo e a posse que este vai deixando em quem escreve o diário. Ele pode absorver em suas páginas tanto os grandes como os pequenos acontecimentos sem nenhuma ordem previamente estabelecida, salvo o que lhes impõe as passagens cronológicas do tempo, daí dizer-se que um diário (cuja frequência de escrita, paradoxalmente, não precisa ser necessariamente diária) não existe fora da gravitação que impõe o fluir do tempo.

Forma privilegiada de inscrição autoral, reinventada em surdina, seu acesso, hoje, funciona como documento para certo conhecimento das maneiras de viver e pensar de determinada época. Os diários, expondo representações da memória familiar e grupal de seu tempo, tornam possível a instauração de teias de sensibilidades pelo conhecimento de detalhes de acontecimentos sociais, culturais e políticos de uma época. Se o diário é ancorado na memória individual, esta é dada a ver pela linguagem, e cabe ao historiador enraizá-la/problematizá-la no rol das experiências sociais, para que cada memória pessoal possa ser vista e estudada como uma perspectiva da memória coletiva.

Por todos estes motivos, o diário pode ser um dos recursos mais importantes para a expressão, o cultivo e a auscultação do íntimo, onde se pode guardar e velar aquilo que constitui uma das facetas para a construção 
de teias de sensibilidades pela descrição da própria intimidade. Os dois conjuntos de diários analisados neste trabalho falam dessas fantasias, projetos, ideias, reflexões, frustrações, medos e sofrimentos, ou seja, aqueles atos internos que escapam aos outros e cujo acesso, aparentemente, lhes está vedado materialmente.

Para este artigo, foram utilizados dois conjuntos de diários escritos por duas mulheres, residentes em Santa Catarina, nas cidades de Florianópolis e Capinzal, entre os anos de 1964 e 1974, doravante identificadas como CL. (Claudete) e M. (Maria). São oito (8) cadernos que registram não só fatos do cotidiano - mil nadas - dessas jovens entre os 14 e 22 anos de idade, mas informações significativas para estudar, pela via do escrito, aspectos da vida cotidiana, sobretudo das experiências vividas naquele período, bem como sobre a vida escolar das protagonistas. Se o cotidiano é, por essência, um espaço banal, um local dos mil nadas, os ritos que o compõem podem ser conhecidos e estudados como representações de uma época onde se pode reconhecer indícios de um tempo que suas autoras quiseram salvar do esquecimento. Estudantes do Curso Normal (Magistério) entre 1965 e 1969, as duas autoras eram jovens urbanas, provenientes das camadas médias da população. O registro diário de suas vidas ordinárias e miúdas foi preservado em álbuns e cadernos escolares, suporte bastante característico destes escritos, considerados como "espaços onde as escolas introduzem os alunos na cultura escrita" (GVIRTZ; LARRONDO, 2008, p. 36). Atualmente, eles fazem parte de meu acervo pessoal e seus escritos se inserem, como as cartas, na clave das escritas ordinárias.

\section{Nos diários, sensibilidades múltiplas}

CL., uma das autoras, inicia seu diário no dia 14 de agosto de 1964, uma sexta-feira. Tem 15 anos de idade e faz o registro movida por dois acontecimentos: ganhou de uma tia um álbum pequeno, com capa perolizada, ostentando um ramalhete de cravos vermelho, onde se lê na capa Меu Diário, e parece ter sido movida a escrever diariamente pela leitura de um livro muito comum em bibliotecas destinadas a jovens católicas dos 


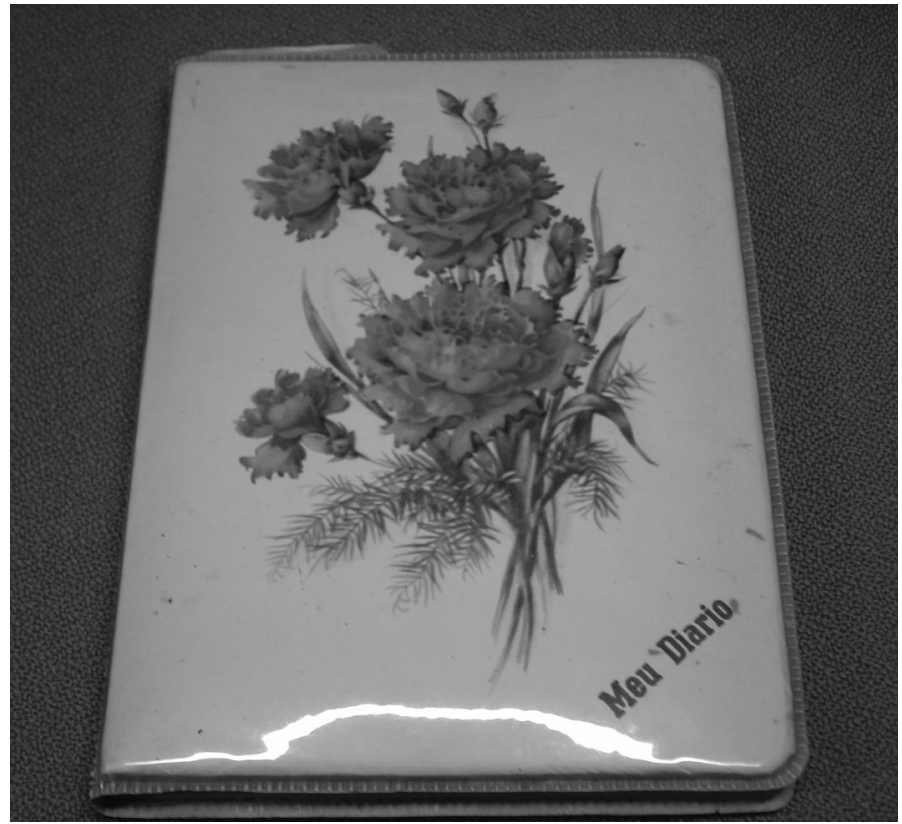

FIGURA 2 - DIÁRIO DE CL.

FONTE: Acervo de CL. digitalizado.

anos 60 do século XX, chamado $O$ diário de Ana Maria, de autoria do padre francês Michel Quoist ${ }^{6}$.

Ecos da religiosidade católica pregada e exercida na casa e na escola aparecem frequentemente nos registros pessoais/íntimos dos diários em estudo e marcam as etapas da vida de jovens católicas preenchidas pelo registro das missas assistidas, dos rituais de batizado, casamento na família, das datas religiosas consagradas, das orações e dos santinhos, muitos deles objetos-relíquia esquecidos nas páginas dos diários. Este expediente permite avaliar a força da Igreja Católica na formação de um imaginário, ainda que as autoras cursassem escolas laicas.

6 Publicado no Brasil em 1960, pela Editora e Livraria Agir (RJ), recebeu aprovação da Igreja Católica. Era considerado um livro de formação. $O$ diário de Ana Maria era dirigido às meninas/ adolescentes e o Diário de Dany aos meninos/adolescentes. 


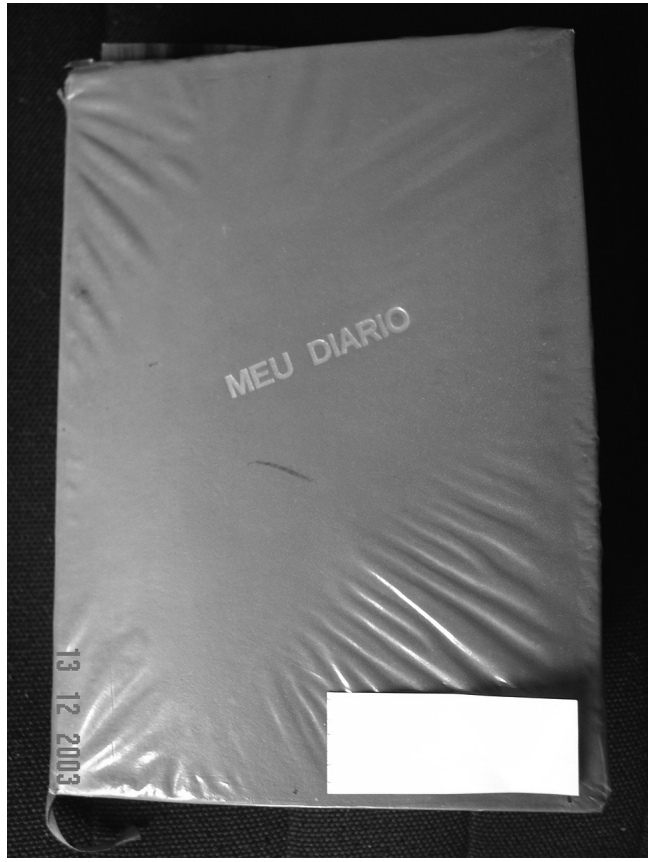

FIGURA 3: DIÁRIO DE M.

FONTE: Acervo pessoal da autora.

Nesse gênero narrativo, embora a ênfase recaia sobre o universo das experiências privadas, é possível encontrar aspectos do mundo público que permitem mostrar, ao mesmo tempo, a importância do sujeito individual aumentada à custa do coletivo.

No Diário de CL., as anotações são inúmeras e permitem inferir um tempo marcado pelas festas da Igreja. Alguns exemplos:

Sábado, 15 de agosto de 1964 (Assumpção - dia santo) Comecei mal o dia, não fui à missa das 8 h de branco.

Domingo, 10 de outubro de 1964.

Missa das 8 h de branco, comunhão geral. 
Domingo, 24 de dezembro de 1967

Natal! Que dia fabuloso! Levantamos em cima da hora e a missa já estava no ofertório. Comunguei. O almoço foi animado com conversas e debates. À noite fomos à missa todos juntos. Na volta, cantamos Noite Feliz!. Trocamos presentes e cartões. Estou em paz com o Senhor!

No Diário de M., por sua vez, as referências religiosas são mais breves no que diz respeito ao cumprimento dos rituais católicos, mas a presença da religião está assegurada pela internalização de uma linguagem piedosa, pelas invocações frequentes aos santos e a Deus:

Sábado, 06 de maio de 1967

Hoje, graças a Deus, passei um dia feliz!

Terça-feira, 09 de maio de 1967

Começo novamente a novena para Santa Teresinha.

Quarta-feira, 28 de junho de 1968

Na aula de didática fizemos um debate sobre Divórcio.

Dona G. é a favor dele. Eu e muitas outras somos contra. Eis, em síntese, meu argumento:

Eu acho que os homens não podem separar aquilo que a lei de Deus uniu, ademais, existem o namoro e o noivado que, a meu ver, são uma preparação para o casamento.

Ainda na esteira da religiosidade, as datas máximas da cristandade são destacadas pelas diaristas, como o dia de Natal e o dia de Ano Novo, apresentados como ícones de todos os prazeres familiares, em que a família reunida se retempera para os revezes e alegrias da vida que prosseguirá. Os registros fornecem informações detalhadas sobre a dieta a ser consumida na ceia natalina e sobre a troca de presentes que sinalizam para uma singeleza na qual objetos simples têm a primazia e a modernidade se insinua sob a forma de toca-discos, rádio de pilhas, discos de vinil, telegramas, roupas tecidas em fios sintéticos, utensílios de plástico, objetos de uso pessoal como perfumes, talcos, anáguas, pó de arroz, utensílios para maquiagem. 
do de nycron, 1 slack preto de helanca, 1 corpete, 1 anágua, 1 sabonete, um perfume Promessa. (Diário de CL.)

Quarta-feira, 25 de dezembro de 1968

A maior surpresa tive hoje ao receber um telegrama do meu amor, que colarei aqui. Ganhei um corte de tergal para uma saia, um disco do Roberto Carlos e uma cinta-liga. Adorei! (Diário de M.)

M., outra das autoras, inicia a redação de suas memórias em 2 de outubro de 1966, um domingo, e também faz referências ao Diário de Ana Maria. Seu objeto de registro é simples: um caderno escolar encapado com plástico incolor e com a inscrição em dourado - Meu Diário. O início do ano de 1968 é registrado por M., aos 16 anos, de forma prosaica, com a narrativa de um dia festivo, há promessas de alegrias futuras e uma listagem das quinze (15) músicas mais tocadas nas rádios da cidade.

Segunda-feira, $1^{\circ}$ de janeiro de 1968.

Mais um ano se passou. Um ano com todos os seus dias e horas, acontecimentos e vida. Espero com confiança que o novo ano traga paz saúde e amor. Que o Brasil esteja bem... anda feio! As músicas classificadas foram 15: "O bom rapaz" (Wanderlei Cardoso); "A praça" (Ronnie Von); "Coração de papel” (Sérgio Reis); "O meu grito!” (Agnaldo Timóteo); "Bus Stop” (Rolling Stones); "A namoradinha de um amigo meu” (Roberto Carlos); "Disparada" (Jair Rodrigues); "Eu te amo mesmo assim" (Martinha); "Maria, carnaval e cinzas" (Roberto Carlos); "Gina”, "See you in September"; "Coisinha Estúpida”...

As preferências musicais de CL. também sinalizam gostos musicais que podem ser pensados como derivados das propagandas e estilos musicais da época, conforme um registro feito no carnaval de 1967, passado em Curitiba:

06/02/1967 Segunda/ Carnaval! Curitiba

O dia amanheceu lindo e aproveitamos para ir ao Passeio Público tirar fotos. Depois fomos tomar refrigerantes e comer pastéis. Na volta, encontramos uma casa de discos em liquida- 
ção. Ficamos doidas e escolhendo e acabamos trazendo uma porção: Renato e seus Blue Caps, Roberto Carlos, Quarteto em Cy com a Banda, Wanderley Cardoso.

Embora a seleção musical apontada pelas duas diaristas possa merecer outros estudos (afinal, a maioria das músicas era nacional, com títulos e letras simples), o que se destaca aqui é o caráter romântico das músicas vencedoras ao lado do breve registro de $\mathrm{M}$. de que o país anda feio. Não há nenhum indício do que isto poderia significar, mas o prosseguimento das anotações ao longo desse ano de 1968 vai evidenciar outras formas de compreender como as pessoas comuns vivenciavam acontecimentos marcantes, como sujeitos singulares registravam um entendimento do tempo histórico a partir de experiências pessoais.

M., nesse primeiro dia do ano de 1968, aos 17 anos, continua a contar fragmentos de sua vida cotidiana, onde se podem notar as condutas corriqueiras que não apontam para qualquer sentido mais "politizado", o que leva à interrogação: esta vida cotidiana parece evidenciar que, independente de ditaduras e guerras, vive-se, há desejos e que a aventura do pensamento exige uma multiplicidade de registros. Dos mais banais aos mais profundos, dos mais íntimos aos mais públicos.

Segunda-feira, $1^{\circ}$ de janeiro de 1968.

Dia típico de verão: sol maravilhoso. Comunguei na missa das sete. Ontem fui dançar ao som de "Alegria, alegria", de Caetano Veloso. Linda. Gosto da parte: o sol se reparte em crimes, espaçonaves, guerrilhas. Será?... Bendito dia $1^{\circ}$ de janeiro de 1968.

A partir desses registros pode-se, para além do anedotário que este material provoca, tentar compreender um capital de vivências no quadro de uma memória pessoal que construiu um território de subjetividades. Subjetividades que vão sendo construídas e contadas nos dias simples, mas que, articuladas com outros documentos, podem, por contiguidade, construir uma narrativa do vivido. Os registros fornecem indícios de como as autoras praticam significações, trazendo as marcas do período em estudo. Assim, parece correto inferir que CL. e M. tecem cotidianamente uma rede 
de relações e escolhas, afirmando seus afetos no contraditório jogo de forças que a vida social lhes impõe.

Já em abril de 1968, M. faz um longo registro sobre a situação política e escolar e é aqui que o relato pode se constituir em mais um elemento para se conhecer como esta fase foi vivenciada tanto pela autora como pela cidade. Diferente da missivista anterior, o relato evidencia preocupações políticas. Ela relata:

Terça-Feira, 2 de abril de 1968

O Instituto de Educação está em greve. Tudo por causa da morte no Rio de Janeiro de um estudante secundarista: Edson de Lima Souto. O rapaz foi assassinado quando protestava contra as más condições da comida do Restaurante Calabouço e também contra a ditadura do atual governo e o imperialismo americano no Brasil. Hoje a passeata foi aqui, embora com chuva tinha bastante gente. Avistei a Stella, professora de Geografia. Onde andarão as outras? Havia poucas professoras.

Ao salientar a ausência de professoras/mulheres no evento político e contestatório, podem-se encontrar subsídios para uma maior compreensão da vida na cidade naquele período. São contribuições à História que se fazem em outros suportes para além dos tidos como convencionais e permitem perceber uma movimentação no período e mais que o fato privado relatado - a ausência da protagonista na passeata - registra-se aqui o fato público - havia poucas professoras. $O$ texto citado parece bastante esclarecedor de que essas vozes, ainda que tímidas, são promotoras da visão da diferença; elas existem e não podem ser perdidas para a História.

No mesmo período - o conturbado ano de 1968 -, o diário de M. também registra:

22 de abril de 1967/ O dia está belíssimo.

O céu não tem nem uma nuvem, está purpuramente azul. Tudo isso é belo e vai bem no fundo da minha alma. Adoro ficar contemplando estas maravilhas da natureza. Ao longe os pássaros cantam felizes e os urubus escalam os céus em voo rápido e audacioso. Nestas belas tarde de outono, eu sonho, sonho e sonho... Não poso parar de sonhar. Acho que tenho dentro de mim alguma coisa que me leva ao mundo irreal dos 
devaneios. Imagino-me nos braços do meu amor, envolvida em carícias que fazem a gente delirar. Recebendo e retribuindo seus beijos apaixonados. Oh! Como é bom sentir o contato do seu corpo junto ao meu...

CL., por sua vez, copia um "pensamento" de Amado Nervo 7 , segundo ela, uma leitura escolar e cujo destaque no diário parece estar associado ao caráter romântico perseguido pela autora:

\section{(23/02/1967) quinta-feira}

Nós fundamentamos nossa vida no amor, eles na transcendência econômica. Onde está o Amor? Ele deve existir em potencial nos seres humanos e o que vejo sempre é o egoísmo. Não devo sucumbir, sei que o que vale é o amor, não importa se o objeto a quem dedicamos o amor seja indigno. Se existir um vazio em tua vida, encha-o de amor.

No mesmo dia, ela faz um comentário em seu caderno nos seguintes termos:

(23/02/1967) quinta-feira

O Beto está bonitão. É querido e atencioso. Notei isso, ontem, antes de fechar a porta, perguntou se eu tinha medo de dormir sozinha. Adormeci pensando que um nada basta para a gente ficar gostando de alguém.

Uma descrição romântica da natureza se anuncia junto a um registro que evidencia uma dada sensibilidade que é construída e recobre diferentes práticas, estados de espírito, sensações físicas, uma relação não apenas racional, mas sensível e perceptível em descrições açucaradas sobre a natureza, ressonância talvez de uma educação literária que, por meio da escrita, explicita suas emoções e a sinceridade de seus sentimentos. Pode-se considerar convincentes as interpretações que conseguem pôr em evidência formas de feminilidades associadas a sensibilidades e que escrever de forma romântica se liga a uma certa "objetivação da imagem feminina sempre

7 Amado Nervo, pseudônimo de Juan Crisóstomo Ruiz de Nervo, foi um poeta mexicano (1870-1919). 
acompanhada de significações ambíguas que, no conjunto, produzem representações e modelos" (MARTINS, 2001, p. 158) que nos incitam a pensar em certo fortalecimento dos papéis sociais esperados.

\section{Acabamentos provisórios...}

Tomar conhecimento, hoje, do teor dessas escritas íntimas e dos registros epistolares já trabalhados permite pensar nas diferentes formas acerca das quais se dá a constituição de uma sensibilidade romântica que se subjetiva nos modos pelos quais os sujeitos narram suas vidas. Diários e cartas são locus de subjetivação e estes processos de subjetivação são históricos, plurais e polifônicos. Eles ressignificam e até regulam desejos afetos, sensibilidades. $\mathrm{O}$ indivíduo, ao narrar seu cotidiano, sua passagem pela vida no tempo histórico, explicita, também, uma configuração de si mesmo a partir das múltiplas tensões socioculturais que designam a cultura da chamada contemporaneidade. Documentos dessa espécie apontam para outras estratégias de visibilidade de uma época e permitem observar que, enquanto os arquivos públicos calavam, os documentos privados, agora publicizados, podem fornecem informações e indícios sobre o cotidiano, formas de ver o mundo através de fatos comuns da experiência humana, hábitos, costumes. Contêm, sim, coisas menores, mas o grande poder de lembrança que trazem permite afirmar que a escrita de diários, em sua dupla dimensão histórica e literária, se constitui como um importante instrumento para o conhecimento do capital de vivências de uma época, onde é possível encontrar fragmentos de laços de sociabilidades de um tempo que foram perenizados pela escrita.

Os benefícios de trabalhar com esses documentos precisam ser mais capturados: além de contribuir para ampliar o repertório de construções de outros modos de subjetivação e outras teias para criar sensibilidades, lê-los foi um maravilhoso exercício de raciocínio e imaginação. De forma inacabada, sempre fica um desejo muito humano de compreender estes outros no tempo, ultrapassando as barreiras da distância temporal e cultural, pois que o "historiador é um construtor do passado nas andanças do presente" (ALBUQUERQUE JÚNIOR, 2007, p. 249). 
Um exame dos suportes aqui analisados (cartas e diários) permite pensar sua pluralidade e polifonia afetiva, evidenciadas em uma estrutura linguística formatada pela padronização narrativa, pelo uso das frases de efeito e chavões, com recurso ao estilo rebuscado. Considerar esta dimensão sensível constitui-se em um exercício de ressignificações de situações que foram, durante muito tempo, desconsideradas por historiadores envolvidos com modalidades racionais, científicas, não emotivas, inauguradas pela modernidade.

De remoto, ingênuo, pueril e romântico, o campo dos sentimentos, das afeições, sensibilidades e percepções adquire outro estatuto e abre um espaço novo para o historiador, a partir do qual a história pode ser repensada. Colocar em cena estes objetos permite pensar nesses materiais como portadores e construtores de teias de sensibilidades na História, considerando que eles são tributários de diferentes situações que envolvem afetividades e que podemos refletir sobre as mesmas como práticas e registros que ocorrem em espaços diversificados e temporalidades distintas. Por meio da fixação proporcionada pela escrita, a memória elaborada pelas jovens em seus diários, a memória que transitou em cartas entre o Paraná e Santa Catarina, transcendeu a fragilidade daquele presente e se inscreveu no tempo da história e do historiador, que também, ao analisá-la, se inventou como sujeito de linguagem.

Por sermos seres de memória, por e para lembramos, o estudo destas práticas de escrita faz sentido para que se possa ser capaz de interpretar frequências, ritmos, emoções, sensações, prazeres e desgostos humanos. Em suma, formas de viver seus prazeres, como suas decepções e tristezas, que navegam da corrente pulsante do coração às mãos que seguram a caneta para perenizar a vida pela escrita. Resta dizer, ainda, que as falhas da memória também permitem a interpretação dos indícios deixados para a compreensão dos fundamentos de nossa contemporaneidade.

\section{Referências}

ALBUQUERQUE JÚNIOR, D. M de. História. A arte de inventar o passado. Bauru: SP: EDUSC, 2007. 
BARNES, Julien. O sentido de um fim. Rio de Janeiro: Rocco, 2012. (Prêmio Man Booker Prize 2011.)

BOLLÉME, Geneviéve. O povo por escrito. São Paulo: Martins Fontes, 1988.

CHARTIER, R. A ordem dos livros. Leitores, autores e bibliotecas na Europa entre os séculos XIV e XVIII. Brasília: Editora da UnB, 1994.

CAMARGO, Maria Rosa M. Cartas adolescentes. Uma leitura e modos de ser... In: MIGNOT, A. C. V.; BASTOS, M. H. C.; CUNHA, M. T. S. (Orgs.). Refúgios do Eu. Educação, História, Escrita Autobiográfica. Florianópolis: Mulheres, 2000. p. 203-228.

CARVALHO, Marcelino. Guia de boas maneiras. 20. ed. São Paulo: Companhia Editora Nacional, 1989.

CASTILLO GÓMEZ, Antonio Un archipiélago desconocido. Archivos y escrituras de la gente común. Arquivamos. Revista Trimestral de la Asociación de Archiveros de Castilla y Leon, Castilla y Leon, v. 38, 2000.

(Ed.). Cultura escrita e clases subalternas: una mirada española. Madrid: Sendoa, 2001.

CATANI, Denice Bárbara et al. História, memória e autobiografia na pesquisa educacional e na formação. In: CATANI, Denice Bárbara et al. (Orgs.). Docência, memória e gênero. Estudos sobre formação. São Paulo: Escrituras, 1997.

CUNHA, Maria Teresa Santos. "Por hoje é só". Cartas entre amigas. In: BASTOS, Maria Helena Câmara; CUNHA, Maria Teresa Santos; MIGNOT, Ana Chrystina Venâncio (Orgs.). Destinos das letras: história, educação e escrita epistolar. Passo Fundo (RS): Editora da UPF, 2002. p. 181-203.

. Diários pessoais. Territórios escritos para a História. In: PINSKY, Carla Bassanezi; DE LUCA, Tania Regina (Orgs.). O historiador e suas fontes. São Paulo: Contexto, 2009. p. 251-280.

DAUPHIN, Cécile; POUBLAN, Danièle. Maneiras de escrever, maneiras de viver. Cartas familiares no século XIX. In: BASTOS, Maria Helena Câmara; CUNHA, Maria Teresa Santos; MIGNOT, Ana Chrystina Venâncio (Orgs.). Destinos das letras: história, educação e escrita epistolar. Passo Fundo (RS): Editora da UPF, 2002. p. 75-88.

ERTZOGUE, Marina H.; PARENTE, Temis Gomes (Org.). História e sensibilidade. Brasília: Paralelo 15, 2006.

FABRE, D. (Org.). Par écrit. Ethinologie des écritures quotidiennes. Paris: Maison des Scinces de L'Homme. 1997. p. 11-30. 
FOISIL, Madeleine. A escritura de foro privado. In: CHARTIER, Roger (Org.). História da vida privada, 3: da Renascença ao Século das Luzes. São Paulo: Companhia das Letras, 1991. p. 331-369.

FOUCAULT, M. O que é um autor? Lisboa: Passagens, 2000.

GVIRTZ, Silvina; LARRONDO, Marina. Os cadernos de classe como fonte primária de pesquisa. In: MIGNOT, Ana Chrystina Venâncio. Cadernos à vista. Escola, memória e cultura escrita. Rio de Janeiro: EDUERJ, 2008. p. 35-48.

HARTOG, François. Tempo e patrimônio. Varia Historia, Belo Horizonte, v. 22, n. 36, p. 261-273, jul.-dez. 2006.

HÉBRARD, J. Por uma bibliografia material das escrituras ordinárias: a escritura e seus suportes. In: MIGNOT, Ana Chrystina Venâncio; BASTOS, Maria Helena Câmara; CUNHA, Maria Teresa Santos (Orgs.). Refúgios do Eu. Educação, História, Escrita Autobiográfica. Florianópolis: Mulheres, 2000. p. 29-61.

LOURO, Guacira Lopes. Mulheres em sala de aula. In: DEL PRIORE, M. (Org.). História das mulheres no Brasil. São Paulo: Contexto, 1997. p. 443-481.

LYONS, Martyn. A palavra impressa: histórias da leitura no século XIX. Rio de Janeiro: Casa da Palavra, 1999.

MARTINS, Ana Paula Vosne. O caso Nana: representações de gênero no encontro entre texto e imagem no século XIX. História: Questões \& Debates, Curitiba: Ed. UFPR, ano 18, n. 34, p. 157-174, jan.-jun. 2001.

PERROT, M. Introdução. In: . História da vida privada: da Revolução Francesa à Primeira Guerra. São Paulo: Companhia das Letras, 1991.

PESAVENTO, Sandra. Na contramão da vida: razões e sensibilidades dos filhos malditos de Deus (Antônio Rasgado, Benjamin, o Degolador, João Foguista). In: ERTZOGUE, M. H.; PARENTE. T. G (Orgs.). História e sensibilidade. Brasília: Paralelo 15, 2006. p. 161-177.

VIÑAO FRAGO, A. Leer y escribir. Historia de dos prácticas culturales. México: Fundacción Educación Voces y Vuelos, 1999.

VICENTINI, Paula Perin. Imagens e representações na história da profissão docente no Brasil (1945-1964). Relatório do Exame de Qualificação (Doutorado/USP), 2000, especialmente o item 3. "Prestígio e pobreza: o Dia do Professor na história da profissão docente". p. 78-101.

Recebido em outubro de 2013. Aprovado em novembro de 2013. 